\title{
Identification and antibiotic susceptibility of lactobacilli isolated from turkeys
}

\author{
Marta Dec ${ }^{1 *} \mathbb{D}$, Anna Nowaczek¹, Dagmara Stępień-Pyśniak', Jacek Wawrzykowski ${ }^{2}$ and Renata Urban-Chmiel ${ }^{1}$
}

\begin{abstract}
Background: The aim of this study was to identify Lactobacillus isolates derived from turkeys from six Polish farms and to characterize their phenotypic and genotypic antibiotic resistance profiles.

Results: Among 62 isolates identified by MALDI-TOF mass spectrometry and restriction analysis of 16S rDNA, the dominant species was L. salivarius (35\%), followed by L. crispatus (21\%), L. ingluviei (14.5\%) and L. johnsonii (10\%). A high prevalence of resistance to tetracycline (68\% resistant isolates), lincomycin (64.5\%) and enrofloxacin (60\%) among the lactobacilli tested was observed. Fewer than $50 \%$ isolates were resistant to ampicillin (47\%), erythromycin (45\%), streptomycin (31\%), chloramphenicol (29\%) and gentamicin (10\%). As many as 64,5\% of the isolates showed multidrug resistance. High MIC values for ampicillin $(\geq 64 \mu \mathrm{g} / \mathrm{ml})$ were usually accompanied by elevated MICs for cephalosporins ( $\geq 16 \mu \mathrm{g} / \mathrm{ml}$ ) and high MICs for tiamulin, i.e. $\geq 32 \mu \mathrm{g} / \mathrm{ml}$, were noted in most of the turkey lactobacilli (61\%). The occurrence of resistance genes was associated with phenotypic resistance, with the exception of five phenotypically susceptible isolates that contained the tetM, tetL, ermC, ermB or cat genes. The most frequently identified were ermB (45\% isolates), tetL (40\%), tetW (37\%) and tetM (29\%), and the occurrence of InuA (18\%), cat (10\%), ermC (6\%), ant(6)-la (5\%) and aadE (5\%) was less frequent. The mechanism of ampicillin resistance has not been elucidated, but the results of nitrocefin test confirmed that it is not involved in the production of beta-lactamases.

Conclusions: The high rate of antibiotic resistance observed in this study indicates the need to implement the principles of rational use of antibiotics in poultry. The presence of transmissible resistant genes in lactobacilli may contribute to the development of antibiotic resistant pathogenic strains that pose a threat to both poultry and consumers. The results of these studies may be useful for committees providing guidance on antibiotic susceptibility of microorganisms in order to revise and supplement current microbiological cut-offs values within the genus Lactobacillus.
\end{abstract}

Keywords: antibiotic susceptibility, Lactobacillus, poultry, resistance genes

\section{Background}

Bacteria of the genus Lactobacillus are Gram-positive, aerotolerant or anaerobic catalase-negative rods or coccobacilli with a $\mathrm{G}+\mathrm{C}$ content usually below $54 \mathrm{~mol} \%$ [1]. They are the most numerous group of lactic acid bacteria (LAB), with 228 species described to date (July 2018) [2]. Based on the 16S rRNA gene sequence, lactobacilli have been divided into 15 large phylogenetic groups, 7 small groups of two species each, and 7 groups represented by

\footnotetext{
*Correspondence: marta.dec@up.lublin.pl; martde16@gmail.com ${ }^{1}$ Department of Veterinary Prevention and Avian Diseases, Institute of Biological Bases of Animal Diseases, Faculty of Veterinary Medicine, University of Life Sciences in Lublin, Akademicka 12, 20-033 Lublin, Poland Full list of author information is available at the end of the article
}

single Lactobacillus species [3]. Due to their high nutritional requirements, lactobacilli colonize environments rich in carbohydrate-containing substances: they are found on plants or material of plant origin, in fermented food products, or in association with mucous membranes of humans and animals. Lactobacillus species found in the gastrointestinal tract (GIT) have received a great deal of attention due to their health-promoting properties. By acidifying the intestines and through other antimicrobial mechanisms, they help to eliminate unfavourable microflora and maintain a natural microbial balance. Their positive effect on host also includes improved digestion and adsorption of nutrients, modulation of immune response and reduction of toxic and mutagenic compounds in the

(c) The Author(s). 2018 Open Access This article is distributed under the terms of the Creative Commons Attribution 4.0 International License (http://creativecommons.org/licenses/by/4.0/), which permits unrestricted use, distribution, and 
gut and serum cholesterol level [4]. Selected strains of Lactobacillus are used as probiotics for humans and animals, and interest in applications for these bacteria continues to grow.

The poultry industry is one of the fastest-growing segments of the livestock sector worldwide. Poland currently remains the largest producer and leading exporter of poultry meat in the European Union. Domestic production consists mainly of broiler chickens, but in recent years there has also been an increase in turkey meat production, which is currently estimated at over 400,000 tonnes per year [5]. Broiler turkey meat is valued all over the world for its delicate taste, low fat content and high levels of valuable protein. However, turkeys are considered difficult to raise, especially in the early stages, due to their sensitivity to adverse environmental conditions and high nutritional requirements [6]. They are also susceptible to many diseases, including bacterial infections, which can be primary or secondary [7].

These problems contribute to the frequent use of antibiotic drugs in turkey farming. Unfortunately, in many cases antibiotic therapy is not used rationally, which greatly contributes to the development of antibiotic resistance among bacteria, both pathogenic and commensal. The GIT, which is inhabited by a large number of diverse bacteria, is considered a reservoir of resistance genes [8]. In such a microbiologically rich environment, it may be possible to exchange genetic material between pathogenic, potentially pathogenic and non-pathogenic bacteria. It has been demonstrated that genetic resistance determinants located on mobile elements, such as plasmids, can be transferred horizontally not only between different Lactobacillus species but also to other species such as potentially pathogenic enterococci [9].

Bacteria, including lactobacilli, become resistant not only via the acquisition of resistance genes from other organisms through horizontal transfer (conjugation, transformation and transduction), but also by de novo mutation. The most well-known mechanisms of bacterial resistance include: i) modifications of the antimicrobial target (decreasing the affinity for the drug), ii) decreased permeability of a bacterial cell wall for drug, iii) activation of efflux mechanisms that extrude the medicine out of the cell, iii) production enzymes that destroy drug's structure, iv) development of an alternative metabolic pathway to those inhibited by the drug [10].

More and newer resistance mechanisms are emerging and spreading globally. Antibiotic-resistant strains propagated in these livestock pose a threat to animals and could be widely disseminated via the food chain. Commensal microflora of the GIT of poultry are frequently present in fresh poultry meat products and may serve as reservoirs of resistant genes that could be transferred to bacterial pathogens of people. Drug-resistant strains cause infections difficult to control and therefore the development of resistance in bacteria is associated with elevated morbidity and mortality rates and increased treatment costs in both animals and humans [11].

Lactobacilli are currently widely used as probiotic supplements, and the strains selected have to meet several criteria, including antibiotic susceptibility. In line with EFSA's FEEDAP Panel (European Food Safety Authority Panel on Additives and Products or Substances used in Animal Feed) recommendations, to differentiate resistant strains from susceptible ones, MIC values should be determined for the number of antibiotics and chemiotherapeutics. Strains showing acquired resistance should not be used as feed additives except when the basis or resistance is chromosomal mutation [12].

The aim of this study was to identify Lactobacillus isolates derived from turkeys, determine their antibiotic susceptibility and detect drug-resistance genes. To the best of our knowledge, no studies have previously been undertaken on characterization of turkey lactobacilli.

\section{Methods \\ Isolation of lactobacilli}

Lactobacillus bacteria were isolated from the fresh faeces or cloacae of 22 healthy turkeys from 6 large-scale poultry farms located in different parts of Poland (Lubelskie, Warmińsko-Mazurskie and Wielkopolskie voivodships). Samples were collected during the period from 2012 to 2013, numbering three or four per farm. The age of the birds ranged from 1 week to 15 weeks. No probiotics were administered on any farm.

Bacteria were isolated on MRS (Man, Rogosa and Sharp) medium (BTL, Poland) at $37^{\circ} \mathrm{C}$ for $48 \mathrm{~h}$ in $5 \% \mathrm{CO}_{2}$. All isolates were Gram-positive and catalase-negative. The strains were kept in deMan Rogosa Sharpe broth (MRS, BTL, Poland) containing $\sim 20 \%$ glycerol at $-80^{\circ} \mathrm{C}$.

\section{Species identification using MALDI-TOF MS}

The MALDI-TOF-MS analysis was done using a UltrafleXtreme MALDI-TOF mass spectrometer (Bruker, Germany). Bacterial colonies were smeared onto stainless steel MALDI MS target plate and overlaid with $1 \mu \mathrm{L}$ of $70 \%$ formic acid before adding $1 \mu \mathrm{L}$ of matrix solution. The analysis of the microbial mass spectra was carried out using MALDI Biotyper 3.0 software (Bruker, Germany) [13].

The results of pattern matching were expressed as numerical score ranging from 0 to 3.00 according to the criteria recommended by Bruker: $\log$ (score) $\geq 2.30$ (2.30$3.00)$ - secured isolate identification at species level, $\log (-$ score) 2.00 to 2.29 - probable identification at the species level, $\log$ (score 1.70 to 1.99 indicates identification at genus level and score $>1.70$ no reliable identification (http://www.bruker.com). The triplicate spot scores 
were recorded and the highest $\log$ (scores) (1.700-3.000) were considered reliable. If the difference between the log values (score) of the two best runs was less than 0.30 , the identification was considered non-significant [13].

\section{Identification of lactobacilli by 16S-ARDRA}

Nine isolates for which definitive species identification was not obtained using MALDI-TOF MS (L. johnsonii/L. gasseri, L. crispatus/L. ultunensis, or $L$. oris/L. antri) were identified using Amplified Ribosomal DNA Restriction Analysis of 16S rDNA (16S-ARDRA). Isolation of bacterial genomic DNA from lactobacilli and amplification of $16 \mathrm{~S}$ rDNA were performed according to the protocol described in our previous work [13].

Eight reference Lactobacillus strains were used in the experiment: L. antri LMG 22111, L. crispatus LMG 9479, L. gasseri LMG 13134, L. gasseri ATCC 19992, L. johnsonii LMG 18195, L. johnsonii LMG 9436, L. oris LMG 9848 and L. ultunensis LMG 22117. The $16 \mathrm{~S}$ rDNA amplicons were digested with 3 restriction enzymes - AluI, MseI and MboI (Thermo Scientific, USA), which were selected on the basis of in silico analysis using CLC Main Workbench software (Qiagen) and the 16S rDNA nucleotide sequences of the Lactobacillus strains, deposited in GenBank.

Ten $\mu \mathrm{l}$ of PCR product was digested in $12.7 \mu \mathrm{l}$ of restriction enzyme buffer containing $0.7 \mu \mathrm{l}$ of enzyme (initial concentration of each restriction enzyme $10 \mathrm{U} / \mu \mathrm{l})$ and left to react at $65^{\circ} \mathrm{C}$ (for $\mathrm{MseI}$ ) or at $37^{\circ} \mathrm{C}$ (for $\mathrm{Alu \textrm {I }}$ and $M b o \mathrm{I}$ ) for $4 \mathrm{~h}$. DNA electrophoresis and analysis of restriction profiles were carried out as described in a previous work [13].

\section{Determination of minimal inhibitory concentration}

Antibiotic susceptibility of all bacterial isolates was determined by the broth microdilution procedure [14], using the LAB susceptibility test medium (LSM) (Iso Sensitest broth containing $10 \%$ of MRS) recommended by ISO 10932/IDF 223 [15]. All dry powder antibiotics were purchased in Sigma-Aldrich (Poland), with the exception of ampicillin, which was obtained from Roth (USA). As the source of enrofloxacin and tiamulin, ready-made solutions of drugs were used (Enrocin, $50 \mathrm{mg} / \mathrm{ml}$, Vet-Agro, Poland and Biomutin, $200 \mathrm{mg} / \mathrm{ml}$, BIOWET DRWALEW S.A. Poland). Cephalosporins were dissolved in water and stock solutions for other antimicrobial agents were prepared as described in our previous work [16].

Fresh cultures grown overnight on LSM medium were used to prepare the bacterial suspensions in $0.9 \% \mathrm{NaCl}$ (final optical density at $600 \mathrm{~nm}$ was 0.5 ). Then, $50 \mu \mathrm{l}$ of a bacterial suspension previously diluted 1:500 in an LSM medium with $50 \mu \mathrm{l}$ of the antibiotic solution were mixed together on a microplate. The plates were incubated $48 \mathrm{~h}$ at $37^{\circ} \mathrm{C}$ in $5 \% \mathrm{CO}_{2}$ and then the MICs were read visually as the lowest concentration of antimicrobial substance that inhibited the growth of bacteria. Enterococcus faecalis ATCC 29212, Lactobacillus johnsonii ATCC 33200 and S. aureus ATCC 29213 were included as a quality control strains (to control of antibiotics potency and quality of medium) $[15,17,18]$. Lactobacillus johnsonii ATCC 33200 were run in parallel with wild-type Lactobacillus isolates in each trial.

The EFSA's FEEDAP Panel guidelines [12] were used to interpret the results ampicillin, tetracycline, erythromycin, streptomycin, gentamicin and chloramphenicol. For lincomycin and enrofloxacin, the criteria suggested earlier by Cauwers et al [19] and Dec et al. [16] were adapted. The bacteria were considered resistant if the MIC was $\geq 64 \mu \mathrm{g} / \mathrm{ml}$ for lincomycin and enrofloxacin. No cut-off values for tiamulin, cephalothin, cefuroxime and ceftiofur were proposed due to insufficient number of isolates and no bimodal MIC distribution for most Lactobacillus species.

\section{Detection of resistance genes}

To detect resistance genes and Tn916/Tn1545-like transposon (integrase gene Int-Tn), 23 gene-specific PCR primer pairs were used (Table 1). The PCR mixture for detection of single resistance genes was prepared in a 25 $\mu \mathrm{l}$ volume containing $2.5 \mu \mathrm{l}$ 10x Dream Taq Buffer, 0.12 $\mu \mathrm{l}$ Dream Taq DNA polymerase $(5 \mathrm{U} / \mathrm{ml}$, Thermo Fisher Scientific), $1.25 \mu \mathrm{l} 8 \mathrm{mM}$ dNTPs mix (Blirt, Poland), 0.8 $\mu \mathrm{l}$ of each of two primers (10 pmol/ $\mu \mathrm{l}$, Sigma-Aldrich, Poland), $1 \mu \mathrm{l}$ template DNA ( 20 ng) and $18.5 \mu \mathrm{l}$ water (Sigma-Aldrich, Poland). Multiplex PCR for detection of some tetracycline, macrolide and aminoglycoside resistance genes (Table 1) was carried out following previously described protocols $[20,21]$.

DNA amplification was performed using an Eppendorf Mastercycler at following conditions: $5 \mathrm{~min}$ at $95^{\circ} \mathrm{C}, 30$ cycles with $40 \mathrm{~s}$ at $95^{\circ} \mathrm{C}, 40 \mathrm{~s}$ at $50-64^{\circ} \mathrm{C}$ (according to the annealing temperature for the individual primers; Table 1) and $75 \mathrm{~s}$ at $72^{\circ} \mathrm{C}$ and $8 \mathrm{~min}$ of final extension at $72^{\circ} \mathrm{C}$. PCR products $(8 \mu \mathrm{l})$ were analysed by electrophoresis $(100 \mathrm{~V})$ on $2 \%$ agarose gels containing ethidium bromide $(0.5 \mathrm{ug} / \mathrm{ml})$.

As a positive control there were used Lactobacillus and Enterococcus wild isolates containing resistance genes as well as reference strain Stapylococcus aureus ATCC 33591 (Table 2). The PCR products obtained for representative wild-type strains were sequenced, and the results of comparative analysis using the NCBI BLAST algorithm (http://www.ncbi.nlm.nih.gov/Blast.cgi) confirmed that the amplicons are counterparts of the resistance genes (Additional file 1).

\section{Nitrocefin test}

In this test Lactobacillus isolates displaying phenotypic resistance to ampicillin were used. A loopful of overnight 
Table 1 Primers used for detection of selected antibiotic resistance genes

\begin{tabular}{|c|c|c|c|c|c|}
\hline Determining resistance to & Target gene & Primer sequence $\left(5^{\prime} \rightarrow 3^{\prime}\right)$ & $\begin{array}{l}\text { Amplicon size } \\
\text { (bp) }\end{array}$ & $\begin{array}{l}\text { Annealing temperature } \\
\left({ }^{\circ} \mathrm{C}\right)\end{array}$ & Reference \\
\hline \multirow[t]{5}{*}{ tetracyclines } & tetM & $\begin{array}{l}\text { GTG GAC AAA GGT ACA ACG AG } \\
\text { CGG TAA AGT TCG TCA CAC AC }\end{array}$ & 406 & 60 & [20] \\
\hline & tetK & $\begin{array}{l}\text { GAT CAA TTG TAG CTT TAG GTG AAG G } \\
\text { TाT TGT TGA TIT ACC AGG TAC CAT T }\end{array}$ & 155 & 60 & \\
\hline & tetl & $\begin{array}{l}\text { TGG TGG AAT GAT AGC CCA TT } \\
\text { CAG GAA TGA CAG CAC GCT AA }\end{array}$ & 229 & 60 & \\
\hline & tetO & $\begin{array}{l}\text { AAC TTA GGC ATT CTG GCT CAC } \\
\text { TCC CAC TGT TCC ATA TCG TCA }\end{array}$ & 515 & 60 & \\
\hline & tetw & $\begin{array}{l}\text { GAG AGC CTG CTA TAT GCC AGC } \\
\text { GGG CGT ATC CAC AAT GTT AAC }\end{array}$ & 168 & 64 & [50] \\
\hline \multirow[t]{5}{*}{$\begin{array}{l}\text { macrolides and } \\
\text { lincosamides }\end{array}$} & ermA & $\begin{array}{l}\text { CCC GAA AAA TAC GCA AAA TाT CAT } \\
\text { CCC TGT TTA CCC ATT TAT AAA CG }\end{array}$ & 590 & 60 & [20] \\
\hline & ermB & $\begin{array}{l}\text { TGG TAT TCC AAA TGC GTA ATG } \\
\text { CTG TGG TAT GGC GGG TAA GT }\end{array}$ & 745 & 60 & \\
\hline & MefA/E & $\begin{array}{l}\text { CAA TAT GGG CAG GGC AAG } \\
\text { AAG CTG TTC CAA TGC TAC GC }\end{array}$ & 317 & 60 & \\
\hline & ermC & $\begin{array}{l}\text { AAT CGT CAA TTC CTG CAT GT } \\
\text { TAATCGTGGAATACGGGTITG }\end{array}$ & 299 & 58 & [35] \\
\hline & InuA & 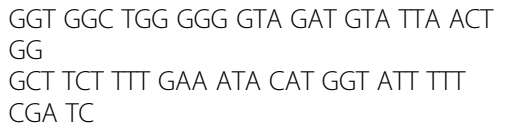 & 323 & 61 & [51] \\
\hline \multirow[t]{8}{*}{ aminoglycosides } & $a a c\left(6^{\prime}\right)-l e-a p h\left(2^{\prime \prime}\right)-1 a$ & $\begin{array}{l}\text { CAG AGC CTT GGG AAG ATG AAG } \\
\text { CCT CGT GTA ATT CAT GTT CTG GC }\end{array}$ & 348 & 56 & [21] \\
\hline & aph3llla & $\begin{array}{l}\text { GGC TAA AAT GAG AAT ATC ACC GG } \\
\text { CTT TAA AAA ATC ATA CAG CTC GCG }\end{array}$ & 523 & & \\
\hline & $a n t\left(4^{\prime}\right)-1 a$ & $\begin{array}{l}\text { CAA ACT GCT AAA TCG GTA GAA GCC } \\
\text { GGA AAG TTG ACC AGA CAT TAC GAA CT }\end{array}$ & 294 & & \\
\hline & $\operatorname{aph}\left(2^{\prime \prime}\right)-1 c$ & $\begin{array}{l}\text { CCA CAA TGA TAA TGA CTC AGT TCC C } \\
\text { CCA CAG CTT CCG ATA GCA AGA G }\end{array}$ & 444 & & \\
\hline & $\operatorname{aph}\left(2^{\prime \prime}\right)-1 d$ & $\begin{array}{l}\text { GTG GTT TाT ACA GGA ATG CCA TC } \\
\text { CCC TCT TCA TAC CAA TCC ATA TAA CC }\end{array}$ & 641 & & \\
\hline & ant(6)-la & $\begin{array}{l}\text { CGG GAG AAT GGG AGA CTT TG } \\
\text { CTG TGG CTC CAC AAT CTG AT }\end{array}$ & 563 & 56 & [52] \\
\hline & $\operatorname{aac}\left(6^{\prime}\right)-l i$ & $\begin{array}{l}\text { TGGCCGGAAGAATATGGAGA } \\
\text { GCATTTGGTAAGACACCTACG }\end{array}$ & 410 & 55 & \\
\hline & $\operatorname{aad} E$ & $\begin{array}{l}\text { ATG GAA TTA TTC CCA CCT GA } \\
\text { TCA AAA CCC CTA TTA AAG CC }\end{array}$ & 1060 & 51 & [43] \\
\hline chloramphenicol & cat & $\begin{array}{l}\text { TAA GGT TAT TGG GAT AAG TTA } \\
\text { GCA TGR TAA CCA TCA CAW AC }\end{array}$ & 340 & 54 & [23] \\
\hline tiamulin & IsaE & $\begin{array}{l}\text { TGT CAA ATG GTG AGC AAA CG } \\
\text { TGT AAA ACG GCT TCC TGA TG }\end{array}$ & 496 & 54 & [53] \\
\hline \multirow[t]{3}{*}{ penicillins } & blaz & $\begin{array}{l}\text { ACT TCA ACA CCT GCT GCT TTC } \\
\text { TAG GTT CAG ATT GGC CCT TAG }\end{array}$ & 240 & 60 & [54] \\
\hline & mecA & $\begin{array}{l}\text { AGT TCT GCA GTA CCG GAT TTG C } \\
\text { AAA ATC GAT GGT AAA GGT TGG C }\end{array}$ & 533 & 55 & [55] \\
\hline & $\begin{array}{l}\text { int-Tn (Tn916/ } \\
\text { Tn1545) }\end{array}$ & $\begin{array}{l}\text { GCGTGATTGTATCTCACT GACGCTCCTGTTGC } \\
\text { TTCT }\end{array}$ & 1028 & 55 & [49] \\
\hline
\end{tabular}


Table 2 Lactic acid bacteria used as positive controls during an experiment to detect resistance genes

\begin{tabular}{|c|c|c|c|}
\hline Isolate & Source & Genotype & Reference \\
\hline L. salivarius $3 a$ & chicken & $\begin{array}{l}\text { IsaE, aac(6')-le-aph(2")-Ia, aadE, } \\
\text { ant(6)-la }\end{array}$ & GeneBank Ac. No. KY924692 \\
\hline $\begin{array}{l}\text { S. aureus ATCC } \\
33591\end{array}$ & $\begin{array}{l}\text { clinical } \\
\text { isolate }\end{array}$ & blaZ, mecA & GeneBank Ac. No. KY264166.1, FJ809758.1 \\
\hline L. salivarius $3 \mathrm{al}$ & turkey & tetL, tetM, ermB, erm C & \multirow{9}{*}{$\begin{array}{l}\text { The sequences of amplicons reflecting the resistance genes and the results of } \\
\text { the comparative analysis with the reference sequences deposited at GenBank } \\
\text { were showed in the Additional file } 1 .\end{array}$} \\
\hline L. salivarius $5 \mathrm{al}$ & turkey & ant(6)-la, aadE, ermC & \\
\hline L. salivarius $27 \mathrm{eCh}$ & chicken & $\operatorname{aph}\left(2^{\prime \prime}\right)-1 c$, tetW, ermB, ant(6)-la & \\
\hline L. salivarius 30al & turkey & tetL, tetM, ermB, int-Tn & \\
\hline L. ingluviei 22el & turkey & tetL, tetW, InuA, ermB, cat & \\
\hline E. faecalis $3 \mathrm{~W}$ & wolf & $\begin{array}{l}\text { tetM, ermB, msrA/B, aph3llla, } \\
\text { ant }\left(4^{\prime}\right)-l a \text {, aac( }\left(6^{\prime}\right)-l e-a p h\left(2^{\prime \prime}\right)-l a \text {, int- } \\
\text { Tn }\end{array}$ & \\
\hline E. faecium $24 \mathrm{~W}$ & wolf & $\operatorname{aac}\left(\sigma^{\prime}\right)-l i$, tet $M, \operatorname{ms} r A / B$ & \\
\hline E. faecium 60 & woodpecker & 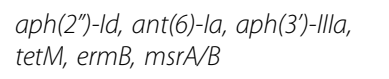 & \\
\hline E. faecalis 140 & chicken & tetO, ant $\left(4^{\prime}\right)-1 a$, int-Tn & \\
\hline
\end{tabular}

culture grown on MRS agar around the ampicillin disks (induction of $\beta$-lactamase production) was smeared on the moisturized nitrocefin strips (DIAGNOSTICS Inc., Slovak Republic). If red color appeared on the strips in 15 min, bacteria were considered as beta-lactamase positive. Three isolates of $E$. coli in which the bla TEM- $1_{\text {gene was }}$ previously detected [22] were used as positive control.

\section{Results}

\section{Identification of lactobacilli}

A total of 62 isolates with rod-shaped morphology were classified as bacteria of the genus Lactobacillus with a Biotyper $\log$ (score) equal to or greater than 1.70. For 4 (6\%) isolates the $\log$ (score) was $2.3-3.0$, for $34(55 \%)$ it was 2.00-2.29, and for 24 (39\%) it was 1.70-1.99 (Additional file 2).

For 53 isolates (85\%) the best matches (1.700-3.000) were considered to be correct species identification. Identification of the remaining 9 strains was considered ambiguous because the first and second best matches (log(score) 1.7-2.3) indicated different species, and the difference between their $\log$ (score) values were less than 0.30 . For 5 of these samples the best match indicated $L$. johnsonii and the second best match $L$. gasseri, for 2 samples the best match indicated L. crispatus and the second best match L. ultunensis, and for another 2 samples the best match indicated L. oris and the second best match L. antri.

Among the 62 isolates identified to the species level (log(score) 1.7-3.0), the species identified were L. salivarius - 22 strains, L. crispatus - $11, L$. crispatus $/ L$. ultunensis - 2, L. ingluviei - 9, L. johnsonii - 1 , L. johnsonii/L. gasseri -5 , L. oris -3 , L. oris/L. antri 2 , L. saerimneri -3 , L. agilis -2 , and L. reuteri -2 strains (Additional file 2).

\section{Identification of lactobacilli using 16S-ARDRA}

Analysis of the electrophoretic profiles obtained by digestion of $16 \mathrm{~S}$ rDNA amplicons with selected restriction enzymes showed that the use of MseI allowed for differentiation between $L$. gasseri and $L$. johnsonii but not between $L$. crispatus and L. ultunensis or between $L$. oris and L.antri. Different electrophoretic profiles for $L$. crispatus and L. ultunensis were obtained only following digestion with $M b o \mathrm{I}$, and differences between $L$. oris and L. antri appeared after digestion with AluI.

Analysis of the electrophoretic restriction profiles showed that all the strains previously identified in MALDI-TOF MS as L. johnsonii/L. gasseri belonged to the species L. johnsonii, 2 isolates identified as L. crispatus/L. ultunensis belonged to the species $L$. crispatus, and 3 species determined as $L$. oris/L. antri belonged to the species L. oris (Fig. 1).

The electrophoretic profiles of digested 16S rDNA amplicons contained 3-6 restriction fragments ranging from 82 to $920 \mathrm{bp}$ (Additional file 3).

\section{Antimicrobial susceptibility testing}

The MIC of 12 antibiotic agents was analysed for 62 Lactobacillus isolates from turkeys. The MIC range was $0.25->64 \mu \mathrm{g} / \mathrm{ml}$ for ampicillin, $0.25-64 \mu \mathrm{g} / \mathrm{ml}$ for cephalothin, $\leq 0.125->64 \mu \mathrm{g} / \mathrm{ml}$ for cefuroxime, $\leq 0.125-64 \mu \mathrm{g} /$ $\mathrm{ml}$ for ceftiofur, $2-512 \mu \mathrm{g} / \mathrm{ml}$ for tetracycline, $\leq 0.25->64$ $\mu \mathrm{g} / \mathrm{ml}$ for erythromycin, $\leq 1->1,024 \mu \mathrm{g} / \mathrm{ml}$ for lincomycin, $\leq 1->1,024 \mu \mathrm{g} / \mathrm{ml}$ for streptomycin, $2->128 \mu \mathrm{g} / \mathrm{ml}$ for gentamycin, $1-128 \mu \mathrm{g} / \mathrm{ml}$ for chloramphenicol, $\leq 0.5->256 \mu \mathrm{g} / \mathrm{ml}$ for tiamulin, and $\leq 1-256 \mu \mathrm{g} / \mathrm{ml}$ for enrofloxacin (Table 3). According to the established criteria, $68 \%$ of isolates were resistant to tetracycline, $64.5 \%$ to lincomycin, $60 \%$ to enrofloxacin, $47 \%$ to ampicillin, 


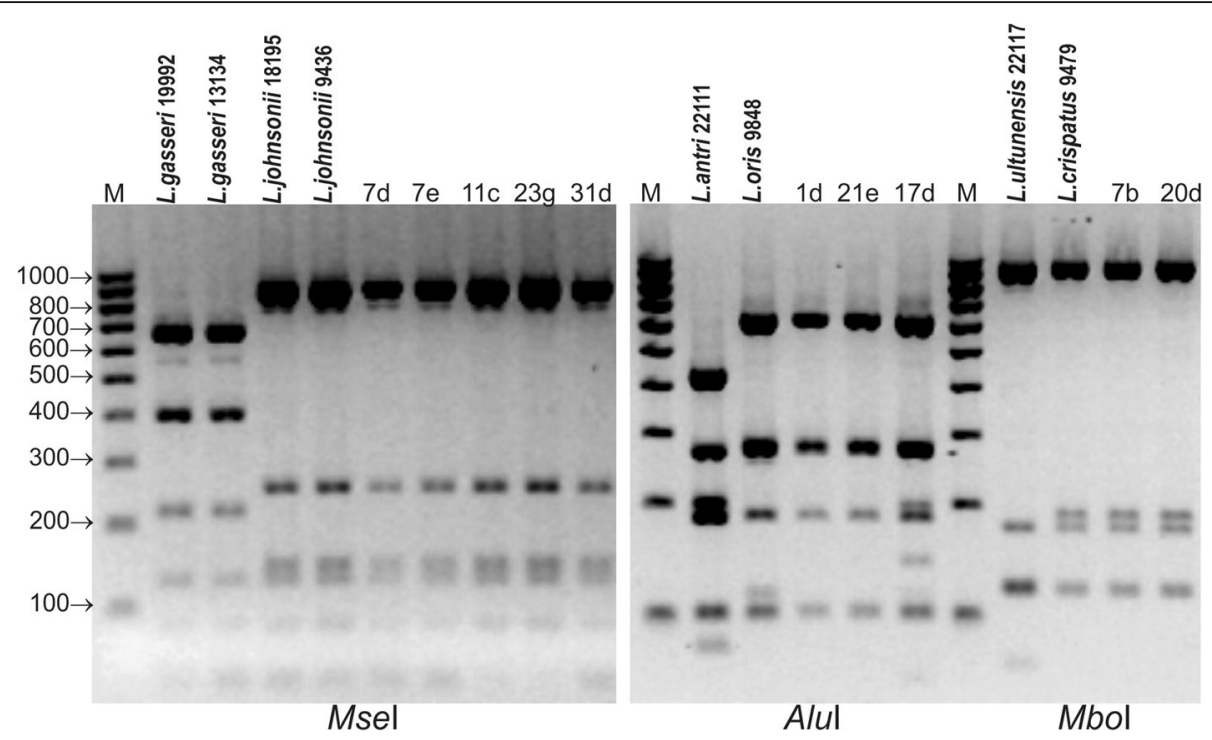

Fig. 1 ARDRA patterns of reference and wild poultry Lactobacillus strains obtained by digestion of 16S rDNA amplicons with Msel, Mbol and Alul

$45 \%$ to erythromycin, $31 \%$ to streptomycin, $29 \%$ to chloramphenicol, and $10 \%$ to gentamicin (Table 4$)$. High MIC values for ampicillin $(\geq 64 \mu \mathrm{g} / \mathrm{ml})$ recorded for 15 (24\%) isolates (L. salivarius and L. crispatus) were usually accompanied by elevated MICs for cephalosporins $(\geq 16 \mu \mathrm{g} / \mathrm{ml}$ ) (Additional file 2). As much as $90 \%$ Lactobacillus isolates showed a MICs range for tiamulin from 2 to $256 \mu \mathrm{g} / \mu \mathrm{l}$, and for $10 \%$ (6) isolates (1 L. reuteri, 2 L. johnsonii and 3 L. ingluviei) we recorded a particularly low tiamulin MICs, ie. $\leq 0.5 \mu \mathrm{g} / \mathrm{ml}$ (Table 3 ). Multiple-drug resistance (resistance to at least 3 groups of antimicrobial agents) was observed for $64.5 \%$ of lactobacilli, and $43.5 \%$ isolates showed cross-resistance between erythromycin and lincomycin. Simultaneous resistance to streptomycin and gentamicin was recorded for $6 \%$ of isolates (Table 4). Only three L. ingluviei isolates (I22b, I23c and I24b), derived from the same farm, showed susceptibility to all the drugs tested, and their MIC values for tiamulin were as low as $\leq 0.5 \mu \mathrm{g} / \mathrm{ml}$ (Table 3).

Clear bimodal distribution of MICs indicative of acquired resistance was observed for erythromycin, lincomycin and tetracycline (for all species beside L. salivarius). Bimodal distribution was also noted for ampicillin MICs for L. johnsonii and L. crispatus isolates and MICs of enrofloxacin for $L$. salivarius, $L$. agilis and L. oris. Regarding the susceptibility of $L$. salivarius to ampicillin and tetracycline, we noted three MIC ranges, which could indicate the presence of sensitive, intermediate and resistant strains. In the case of aminoglycosides, chloramphenicol and tiamulin, distribution of MIC values was unimodal for most Lactobacillus species (Table 3).

\section{Detection of antibiotic resistance genes}

Of the 23 considered resistance genes, 10 were detected in the tested lactobacilli. We found tet genes conferring resistance to tetracyclines in $42(68 \%)$ isolates, including 41 phenotypically resistant to tetracycline and one susceptible strain (it contained tet $M$ and tet $L$ genes). The most frequently identified tet gene was tet $\mathrm{L}$, which was observed in $40 \%$ of isolates, followed by tet $W(37 \%)$ and tetM (29\%) (Table 5). The presence of individual tet genes seems to be correlated with the species. The tetM gene was found in L. salivarius, L. crispatus and L. agilis; tet $L$ was detected in L. salivarius, L. agilis, L. crispatus, L. oris, and in one isolate of L. ingluviei. The presence of the tet W gene was unique for the species belonging to the phylogenetic group of L. delbrueckii (L. johnsonii and $L$. crispatus) and L. reuteri (L. oris, L. ingluviei and $L$. reuteri). The co-occurrence of tet $M$ and tet $L$ was characteristic for $L$. salivarius, $L$. agilis and L. crispatus. The tet $L$ and tet $W$ genes were present simultaneously only in L. crispatus, L. oris and L. ingluviei isolates.

Among the genes coding for resistance to macrolides and lincosamides, the most frequent was ermB (in $45 \%$ of isolates), rarely $\operatorname{erm} C(6 \%)$ and $\ln u A$ (18\%). The rRNA methylase ermB gene was detected in all isolates resistant to erythromycin (27 isolates with $\mathrm{MIC} \geq 64 \mu \mathrm{g} / \mathrm{ml}$ ) and in one isolate with a susceptible phenotype (L. salivarius $21 \mathrm{~b}, \mathrm{MIC}=0.5 \mu \mathrm{g}$ / $\mathrm{ml}$ ) (Tables 3, 5). The ermC gene (encoding methylase) was detected in 4 isolates of $L$. salivarius, including 2 phenotypically resistant to erythromycin and 2 susceptible to this antibiotic. Three of these erm $C$-positive isolates were resistant to lincomycin. 
Table 3 Distribution of MICs of antibiotics among various Lactobacillus species of turkey origin

\begin{tabular}{|c|c|c|c|c|c|c|c|c|c|c|c|c|c|c|c|c|c|}
\hline & $\begin{array}{l}\text { No } \\
\frac{1}{0} \\
\text { VI }\end{array}$ & స్ & $\begin{array}{l}\text { Lo } \\
\text { Vi }\end{array}$ & Ln & $\overline{\mathrm{v}}$ & - & $N$ & $\theta$ & $\infty$ & $\stackrel{0}{\circ}$ & స్ల & $\Xi$ & ఫ્ર & $\stackrel{\stackrel{\infty}{\sim}}{\sim}$ & ณ̊ำ & $\frac{N}{5}$ & ষ্ণ \\
\hline \multicolumn{18}{|l|}{ Ampicillin } \\
\hline L. salivarius $(n=22)$ & & 1 & & 3 & & & 2 & 6 & 1 & & 1 & 6 & 2 & & & & \\
\hline L. agilis $(\mathrm{n}=2)$ & & 1 & & 1 & & & & & & & & & & & & & \\
\hline L. saerimneri $(n=3)$ & & & & & & & 2 & 1 & & & & & & & & & \\
\hline L. johnsonii $(\mathrm{n}=6)$ & & & & 3 & & 2 & & & & & & & 1 & & & & \\
\hline L. crispatus $(\mathrm{n}=13$ ) & & & & 4 & & & & & 1 & 2 & & 3 & 3 & & & & \\
\hline L. oris $(n=5)$ & & & & & & & 1 & & & 4 & & & & & & & \\
\hline L. ingluviei $(\mathrm{n}=9)$ & & & & & & 4 & 3 & 2 & & & & & & & & & \\
\hline L. reuteri $(n=2)$ & & & & & & 1 & 1 & & & & & & & & & & \\
\hline All 62 & & 2 & & 11 & & 7 & 9 & 9 & 2 & 6 & 1 & 9 & 6 & & & & \\
\hline \multicolumn{18}{|l|}{ Cephalothin } \\
\hline L. agilis $(n=2)$ & & & & & & & 1 & 1 & & & & & & & & & \\
\hline L. saerimneri $(n=3)$ & & & & & & & & & 1 & 2 & & & & & & & \\
\hline L. johnsonii $(n=6)$ & & 1 & & 2 & & 2 & & & & & & 1 & & & & & \\
\hline L. crispatus $(n=13)$ & & & & & & 1 & 1 & 2 & 3 & & 4 & 2 & & & & & \\
\hline L. oris $(n=5)$ & & & & & & & 1 & & & 4 & & & & & & & \\
\hline L. ingluviei $(n=9)$ & & & & & & & & 4 & 5 & & & & & & & & \\
\hline L. reuteri $(\mathrm{n}=2)$ & & & & & & & & & & 2 & & & & & & & \\
\hline All 62 & & 1 & & 2 & & 3 & 6 & 14 & 13 & 13 & 6 & 4 & & & & & \\
\hline \multicolumn{18}{|l|}{ Cefuroxime } \\
\hline L. salivarius $(n=22)$ & & 1 & & 2 & & 4 & 2 & 2 & 1 & 2 & 2 & 5 & 1 & & & & \\
\hline L. agilis $(n=2)$ & & & & & & & 1 & 1 & & & & & & & & & \\
\hline L. saerimneri $(n=3)$ & & & & & & & 1 & 2 & & & & & & & & & \\
\hline L. johnsonii $(\mathrm{n}=6)$ & & 1 & & 1 & & 3 & & & & 1 & & & & & & & \\
\hline L. crispatus $(n=13)$ & & & & & & & & 4 & 3 & 2 & 1 & & 3 & & & & \\
\hline L. oris $(n=5)$ & & & & & & & 1 & & & & 4 & & & & & & \\
\hline L. ingluviei $(\mathrm{n}=9)$ & & & & & & 6 & 3 & & & & & & & & & & \\
\hline L. reuteri $(\mathrm{n}=2)$ & & & & & & & 1 & 1 & & & & & & & & & \\
\hline All 62 & & 2 & & 3 & & 13 & 9 & 10 & 4 & 5 & 7 & 5 & 4 & & & & \\
\hline $\begin{array}{l}\text { Ceftiofur } \\
\text { L. salivarius }(n=22)\end{array}$ & \multicolumn{8}{|c|}{ Ceftiofur } & & & & 1 & & & & & \\
\hline L. agilis $(n=2)$ & & & & 1 & & 1 & & & & & & & & & & & \\
\hline L. saerimneri $(\mathrm{n}=3)$ & & & & & & 1 & 2 & & & & & & & & & & \\
\hline L. johnsonii $(n=6)$ & & 2 & & & & 1 & 2 & & & 1 & & & & & & & \\
\hline L. crispatus $(\mathrm{n}=13$ ) & & & & 2 & & 2 & 1 & 2 & & 6 & & & & & & & \\
\hline L. oris $(n=5)$ & 1 & & & & & & & 4 & & & & & & & & & \\
\hline L. ingluviei $(n=9)$ & 1 & 4 & & 4 & & & & & & & & & & & & & \\
\hline L. reuteri $(n=2)$ & & & & 2 & & & & & & & & & & & & & \\
\hline All 62 & 3 & 9 & & 11 & & 7 & 7 & 9 & 3 & 12 & & 1 & & & & & \\
\hline \multicolumn{18}{|l|}{ Tetracycline } \\
\hline L. agilis $(n=2)$ & & & & & & & & & 1 & & & & & & $1^{\text {tet }}$ & $1^{\text {tet }}$ & \\
\hline L. saerimneri $(n=3)$ & & & & & & & & 3 & & & & & & & & & \\
\hline L. johnsonii $(n=6)$ & & & & & & & 1 & & & & & & & $2^{\text {tet }}$ & $3^{\text {tet }}$ & & \\
\hline L. crispatus $(n=13)$ & & & & & & & 2 & & & & & & & $5^{\text {tet }}$ & $3^{\text {tet }}$ & $3^{\text {tet }}$ & \\
\hline L. oris $(n=5)$ & & & & & & & & & 1 & & & & & & $1^{\text {tet }}$ & $3^{\text {tet }}$ & \\
\hline L. ingluviei $(\mathrm{n}=9)$ & & & & & & & & 3 & & 1 & & & & & $4^{\text {tet }}$ & $1^{\text {tet }}$ & \\
\hline L. reuteri $(\mathrm{n}=2)$ & & & & & & & & & 1 & & & & & $1^{\text {tet }}$ & & & \\
\hline All 62 & & & & & & & 3 & 8 & 9 & 1 & 1 & 1 & & 9 & 16 & 14 & \\
\hline \multicolumn{18}{|l|}{ Erythromycin } \\
\hline L. salivarius $(n=22)$ & & $3^{\mathrm{erm} C(1)}$ & & $10^{\mathrm{erm} C(1)}$ & & & & & & & & $\begin{array}{l}4_{e r m C(1)}^{e r m B} \\
\text { erm }\end{array}$ & 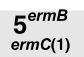 & & & & \\
\hline L. agilis $(\mathrm{n}=2)$ & & 1 & & & & & & & & & & & $1^{\mathrm{ermB}}$ & & & & \\
\hline L. saerimneri $(n=3)$ & & 3 & & & & & & & & & & & & & & & \\
\hline L. johnsonii $(n=6)$ & & 4 & & & & & & & & & & & $2^{\text {ermB }}$ & & & & \\
\hline L. crispatus $(n=13)$ & & 6 & & & & & & & & & & $4^{\mathrm{ermB}}$ & $3^{\text {ermB }}$ & & & & \\
\hline L. oris $(n=5)$ & & 1 & & & & & & & & & & & $4^{\text {ermB }}$ & & & & \\
\hline L. ingluviei $(n=9)$ & & 4 & & & & & & & & & & $1^{\mathrm{ermB}}$ & $4^{\mathrm{erm} B}$ & & & & \\
\hline L. reuteri $(n=2)$ & & 2 & & & & & & & & & & & & & & & \\
\hline All 62 & & 24 & & 10 & & & & & & & & 9 & 19 & & & & \\
\hline
\end{tabular}


Table 3 Distribution of MICs of antibiotics among various Lactobacillus species of turkey origin (Continued)

\begin{tabular}{|c|c|c|c|c|c|c|c|c|c|c|c|c|c|}
\hline \multicolumn{14}{|l|}{ Lincomycin } \\
\hline L. salivarius $(n=22)$ & & & & & 2 & 3 & 1 & $2^{\mathrm{erm} C(1)}$ & 1 & & $3_{I n u A(1)}^{\operatorname{erm} C(1)}$ & $3^{\mathrm{ermB}(2)}$ & $\begin{array}{c}7_{\text {erm }}^{\operatorname{erm}(6)} \\
\ln A_{(2)}(2)\end{array}$ \\
\hline L. agilis $(n=2)$ & & & & & & & 1 & & & & & & $1^{\mathrm{ermB}}$ \\
\hline L. saerimneri $(n=3)$ & & & & & & & 2 & 1 & & & & & \\
\hline L. johnsonii $(\mathrm{n}=6)$ & & & $1^{\mathrm{ermB}}$ & & & & & & & 2 & 2 & & $1^{\mathrm{ermB}}$ \\
\hline L. crispatus $(n=13$ ) & & & & & 1 & 3 & 1 & & & 1 & $2^{\text {ermB }}$ & $5^{\mathrm{ermB}}$ & \\
\hline L. oris $(n=5)$ & & & & & & & & & $1^{\operatorname{lnuA}}$ & & & $4_{\text {InuA }}^{\text {ermB }}$ & \\
\hline L. ingluviei $(\mathrm{n}=9)$ & & 1 & 2 & & 1 & & & & & & & $3^{\text {ermB }}$ & $\underset{\text { InuA(1) }}{2^{\text {erm } B}}$ \\
\hline L. reuteri $(n=2)$ & & & & & & & & & $1^{\ln u A}$ & $1^{\ln u A}$ & & & \\
\hline All 62 & & 1 & 3 & & 4 & 6 & 5 & 3 & 3 & 4 & 7 & 15 & 11 \\
\hline \multicolumn{14}{|l|}{ Streptomycin } \\
\hline L. salivarius $(n=22)$ & & & & & & & & 2 & 9 & 7 & & $\begin{array}{l}3_{a n t(6)-\operatorname{la}(2)}^{\operatorname{aad}(2)} \\
\text { a }\end{array}$ & $\begin{array}{c}1^{\text {aadE }} \\
\text { ant(6)-la }\end{array}$ \\
\hline L. agilis $(\mathrm{n}=2)$ & & & & & & & & & & 2 & & & \\
\hline L. saerimneri $(n=3)$ & & & & & & & & & & 3 & & & \\
\hline L. johnsonii $(\mathrm{n}=6)$ & & & & 4 & 1 & 1 & & & & & & & \\
\hline L. crispatus ( $\mathrm{n}=13$ ) & & 1 & & & 5 & 4 & & 1 & 1 & & & & 1 \\
\hline L. oris $(n=5)$ & & & & & & & 1 & 3 & 1 & & & & \\
\hline L. ingluviei $(n=9)$ & & & & & & & & 3 & 6 & & & & \\
\hline L. reuteri $(\mathrm{n}=2)$ & & & & & & & 2 & & & & & & \\
\hline All 62 & & 1 & & 4 & 6 & 5 & 3 & 9 & 17 & 12 & & 3 & 2 \\
\hline \multicolumn{14}{|l|}{ Gentamycin } \\
\hline L. salivarius $(\mathrm{n}=22$ ) & & & & & 3 & 14 & 4 & & & 1 & & & \\
\hline L. agilis $(n=2)$ & & & & & & 1 & 1 & & & & & & \\
\hline L. saerimneri $(n=3)$ & & & & & & & & 1 & 2 & & & & \\
\hline L. johnsonii $(\mathrm{n}=6)$ & & & & & 5 & 1 & & & & & & & \\
\hline L. crispatus $(n=13)$ & & & & 1 & 6 & 3 & 1 & 2 & & & & & \\
\hline L. oris $(n=5)$ & & & & 4 & 1 & & & & & & & & \\
\hline L. ingluviei $(\mathrm{n}=9)$ & & & & 1 & 4 & 3 & 1 & & & & & & \\
\hline L. reuteri $(n=2)$ & & 2 & & & & & & & & & & & \\
\hline All 62 & & 2 & & 6 & 19 & 22 & 7 & 3 & 2 & 1 & & & \\
\hline \multicolumn{14}{|l|}{ Chloramphenicol } \\
\hline L. salivarius $(n=22)$ & & & 1 & 1 & 11 & 9 & & & & & & & \\
\hline L. agilis $(n=2)$ & & & & 2 & & & & & & & & & \\
\hline L. saerimneri $(\mathrm{n}=3)$ & & & & & 2 & 1 & & & & & & & \\
\hline L. johnsonii $(n=6)$ & & & & 1 & 4 & 1 & & & & & & & \\
\hline L. crispatus $(\mathrm{n}=13$ ) & & & & 5 & 7 & 1 & & & & & & & \\
\hline L. oris $(n=5)$ & & & & & 4 & 1 & & & & & & & \\
\hline L. ingluviei $(\mathrm{n}=9)$ & & & & & $4^{\text {cat(2) }}$ & & 1 & $2^{\text {cat }}$ & $1^{\text {cat }}$ & $1^{\text {cat }}$ & & & \\
\hline L. reuteri $(\mathrm{n}=2)$ & & & & & 2 & & & & & & & & \\
\hline All 62 & & & 1 & 9 & 34 & 13 & 1 & 2 & 1 & 1 & & & \\
\hline $\begin{array}{l}\text { Tiamulin } \\
\text { L salivarius }(n=22)\end{array}$ & & & & & & 4 & & 2 & 5 & $8^{I \operatorname{saE}(1)}$ & $3^{\operatorname{lsaE(2)}}$ & & \\
\hline L. agilis $(n=2)$ & & & & & & & 1 & 1 & & & & & \\
\hline L. saerimneri $(n=3)$ & & & & & & & & & 3 & & & & \\
\hline L. johnsonii $(n=6)$ & 2 & & & & 1 & & & & & 3 & & & \\
\hline L. crispatus $(n=13)$ & & & & & & 2 & 2 & 4 & 3 & 1 & 1 & & \\
\hline L. oris $(n=5)$ & & & & 3 & 1 & 1 & & & & & & & \\
\hline L. ingluviei $(n=9)$ & 3 & & & & 1 & 1 & 2 & 1 & 1 & & & & \\
\hline L. reuteri $(n=2)$ & 1 & & & & & & 1 & & & & & & \\
\hline All 62 & 6 & & & 3 & 3 & 8 & 6 & 8 & 12 & 12 & 4 & & \\
\hline \multicolumn{14}{|l|}{ Enrofloxacin } \\
\hline L. salivarius $(n=22)$ & & & & & 1 & & 1 & & & 6 & 14 & & \\
\hline L. agilis $(\mathrm{n}=2)$ & & 1 & & & & & & & & & 1 & & \\
\hline L. saerimneri $(n=3)$ & & & & & & 2 & 1 & & & & & & \\
\hline L. johnsonii $(\mathrm{n}=6)$ & & & & & & & 1 & 3 & 2 & & & & \\
\hline L. crispatus $(n=13)$ & & & & & & & & & 4 & 9 & & & \\
\hline L. oris $(n=5)$ & & & & & & & 1 & 3 & & 1 & & & \\
\hline L. ingluviei $(n=9)$ & & & & & 1 & 4 & 4 & & & & & & \\
\hline L. reuteri $(n=2)$ & & & & & & 2 & & & & & & & \\
\hline All 62 & & 1 & & & 2 & 8 & 8 & 6 & 6 & 16 & 15 & & \\
\hline
\end{tabular}

Fragments highlighted in grey indicate MIC cut-off values $(\mu \mathrm{g} / \mathrm{mL})$ as indicated in the Methods. The number of isolates carrying the gene in question is given in brackets after the name of the gene. The absence of a number following the name of the gene means that all isolates contain the gene tet $^{*}=$ tetM or tetL or tetW 


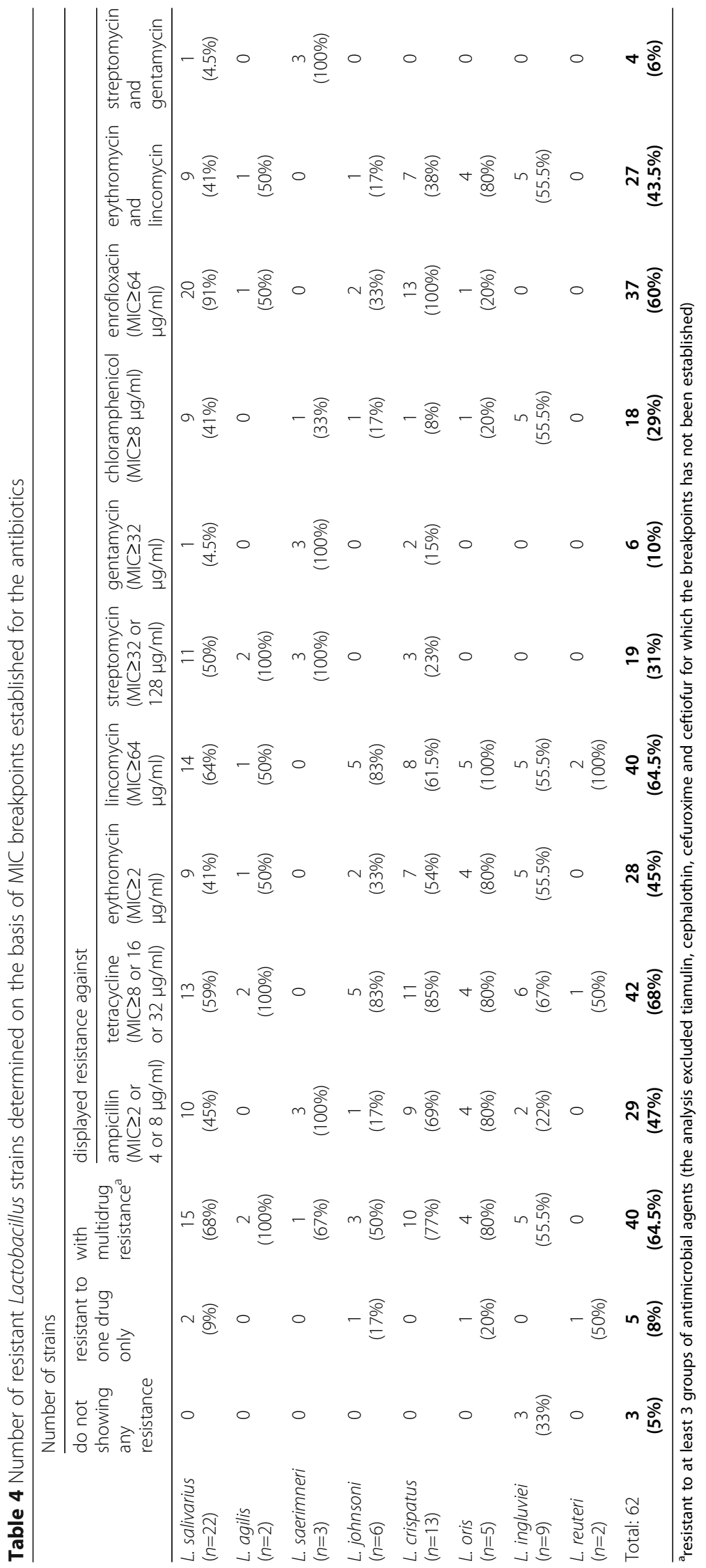


Table 5 Number of Lactobacillus strains carrying resistance genes ${ }^{a}$

\begin{tabular}{|c|c|c|c|c|c|c|c|c|c|c|c|c|c|c|c|}
\hline $\begin{array}{l}\text { Resistant } \\
\text { gene } \rightarrow\end{array}$ & tetL & tetM & tetW & ermB & ermC & $\ln u A$ & $\begin{array}{l}\text { tetL+ } \\
\text { tetM }\end{array}$ & $\begin{array}{l}\text { tet } L+\text { tetM } \\
+ \text { ermB }\end{array}$ & $\begin{array}{l}\text { tet } W+ \\
\text { ermB }\end{array}$ & $\begin{array}{l}\text { ermB } \\
+\operatorname{In} u A\end{array}$ & cat & $\begin{array}{l}\text { ant(6)-la } \\
\text { (aadE) }\end{array}$ & IsaE & $\begin{array}{l}\text { lsaE + } \\
\text { ant(6)-la } \\
(\text { aadE) }\end{array}$ & $\begin{array}{l}\text { int-Tn } \\
\text { (Tn916/ } \\
\text { Tn1545) } \\
\end{array}$ \\
\hline $\begin{array}{l}\text { L. } \\
\text { salivarius } \\
(n=22)\end{array}$ & $\begin{array}{c}14 \\
(64 \%)\end{array}$ & $\begin{array}{c}12 \\
(54.5 \%)\end{array}$ & 0 & $\begin{array}{c}9 \\
(41 \%)\end{array}$ & $\begin{array}{c}4 \\
(18 \%)\end{array}$ & $\begin{array}{c}3 \\
(14 \%)\end{array}$ & $\begin{array}{c}12 \\
(54.5 \%)\end{array}$ & $\begin{array}{c}8 \\
(36 \%)\end{array}$ & 0 & $\begin{array}{c}2 \\
(9 \%)\end{array}$ & 0 & $\begin{array}{c}3 \\
(14 \%)\end{array}$ & $\begin{array}{c}3 \\
(14 \%)\end{array}$ & $\begin{array}{c}3 \\
(14 \%)\end{array}$ & $\begin{array}{c}3 \\
(14 \%)\end{array}$ \\
\hline $\begin{array}{l}\text { L. agilis } \\
(n=2)\end{array}$ & $\begin{array}{c}2 \\
(100 \%)\end{array}$ & $\begin{array}{c}2 \\
(100 \%)\end{array}$ & 0 & $\begin{array}{c}1 \\
(50 \%)\end{array}$ & 0 & 0 & $\begin{array}{c}2 \\
(100 \%)\end{array}$ & $\begin{array}{c}1 \\
(50 \%)\end{array}$ & 0 & 0 & 0 & 0 & 0 & 0 & 0 \\
\hline $\begin{array}{l}L . \\
\text { saerimneri } \\
(n=3)\end{array}$ & 0 & 0 & 0 & 0 & 0 & 0 & 0 & 0 & 0 & 0 & 0 & 0 & 0 & 0 & 0 \\
\hline $\begin{array}{l}\text { L. } \\
\text { johnsonii } \\
(n=6)\end{array}$ & 0 & 0 & $\begin{array}{c}5 \\
(83 \%)\end{array}$ & $\begin{array}{c}2 \\
(33 \%)\end{array}$ & 0 & 0 & 0 & 0 & $\begin{array}{c}2 \\
(33 \%)\end{array}$ & 0 & 0 & 0 & 0 & 0 & 0 \\
\hline $\begin{array}{l}\text { L. } \\
\text { crispatus } \\
(n=13)\end{array}$ & $\begin{array}{c}4 \\
(31 \%)\end{array}$ & $\begin{array}{c}4 \\
(31 \%)\end{array}$ & $\begin{array}{c}8 \\
(61.5 \%)\end{array}$ & $\begin{array}{c}7 \\
(54 \%)\end{array}$ & 0 & 0 & $\begin{array}{c}4 \\
(31 \%)\end{array}$ & $\begin{array}{c}2 \\
(15 \%)\end{array}$ & $\begin{array}{c}4 \\
(31 \%)\end{array}$ & 0 & 0 & 0 & 0 & 0 & 0 \\
\hline $\begin{array}{l}\text { L. oris } \\
(n=5)\end{array}$ & $\begin{array}{c}4 \\
(80 \%)\end{array}$ & 0 & $\begin{array}{c}4 \\
(80 \%)\end{array}$ & $\begin{array}{c}4 \\
(80 \%)\end{array}$ & 0 & $\begin{array}{c}5 \\
(100 \%)\end{array}$ & 0 & 0 & $\begin{array}{c}4 \\
(80 \%)\end{array}$ & $\begin{array}{c}4 \\
(80 \%)\end{array}$ & 0 & 0 & 0 & 0 & 0 \\
\hline $\begin{array}{l}\text { L. ingluviei } \\
(n=9)\end{array}$ & $\begin{array}{c}1 \\
(11 \%)\end{array}$ & 0 & $\begin{array}{c}5 \\
(55.5 \%)\end{array}$ & $\begin{array}{c}5 \\
(55.5 \%)\end{array}$ & 0 & $\begin{array}{c}1 \\
(11 \%)\end{array}$ & 0 & 0 & $\begin{array}{c}5 \\
(55.5 \%)\end{array}$ & $\begin{array}{c}1 \\
(11 \%)\end{array}$ & $\begin{array}{c}6 \\
(67 \%)\end{array}$ & 0 & 0 & 0 & 0 \\
\hline $\begin{array}{l}\text { L. reuteri } \\
(n=2)\end{array}$ & 0 & 0 & $\begin{array}{c}1 \\
(50 \%)\end{array}$ & 0 & 0 & $\begin{array}{c}2 \\
(100 \%)\end{array}$ & 0 & 0 & 0 & 0 & 0 & 0 & 0 & 0 & 0 \\
\hline Total: 62 & $\begin{array}{c}25 \\
(40 \%)\end{array}$ & $\begin{array}{c}18 \\
(29 \%)\end{array}$ & $\begin{array}{c}23 \\
(37 \%)\end{array}$ & $\begin{array}{c}28 \\
(45 \%)\end{array}$ & $\begin{array}{c}4 \\
(7 \%)\end{array}$ & $\begin{array}{c}11 \\
(18 \%)\end{array}$ & $\begin{array}{c}18 \\
(29 \%)\end{array}$ & $\begin{array}{c}11 \\
(18 \%)\end{array}$ & $\begin{array}{c}15 \\
(24 \%)\end{array}$ & $\begin{array}{c}7 \\
(11 \%)\end{array}$ & $\begin{array}{c}6 \\
(10 \%)\end{array}$ & $\begin{array}{c}3 \\
(5 \%)\end{array}$ & $\begin{array}{c}3 \\
(5 \%)\end{array}$ & $\begin{array}{c}3 \\
(5 \%)\end{array}$ & $\begin{array}{c}3 \\
(5 \%)\end{array}$ \\
\hline
\end{tabular}

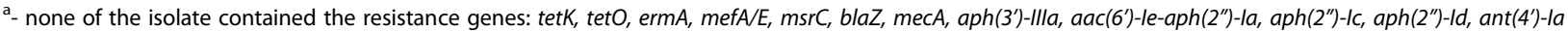
and $\operatorname{aac}\left(6^{\prime}\right)-1 i$

The $\ln u A$ gene (encoding lincosamide $O$-nucleotidyltransferase) was detected in 11 strains, all of which were resistant to lincomycin (Table 3).

Among genes determining resistance to aminoglycoside antibiotics, ant(6)-Ia and aadE encoding ANT(6) adenyltransferases were detected. They occurred simultaneously in 3 isolates $(5 \%)$ of $\mathrm{L}$. salivarius showing resistance to streptomycin $(\mathrm{MIC} \leq 512$ $\mu \mathrm{g} / \mathrm{ml})$. The results of the sequence analysis of PCR products indicated that $a a d E$ and $a n t(6)-I a$ are the same gene detected by different primers (Additional file 1).

The cat gene encoding chloramphenicol acetyltransferase, which converts chloramphenicol to inactive diacetyl chloramphenicol [23], was present in 6 isolates $(11 \%)$ of L. ingluviei, 4 of which were resistant to chloramphenicol $(\mathrm{MIC} \leq 8 \mu \mathrm{g} / \mathrm{ml})$ (Tables 3, 5).

The $l s a E$ gene coding for multidrug efflux pumps was present in 3 isolates of L. salivarius with high MIC values for tiamulin, i.e. $>256 \mu \mathrm{g} / \mathrm{ml}$ (Tables 3, 5). These $l s a E$-positive isolates also contained the $a a d E$ or ant(6)-Ia gene conferring resistance to streptomycin.

None of the Lactobacillus isolates contained the tetK, tetO, ermA, mefA/E, blaZ, mecA, aph(3')-IIIa, aac(6')-Ie-aph(2")-Ia, aph(2")-Ic, aph(2")-Id, ant(4')-Ia or aac(6')-Ii genes. The int-Tn gene, encoding the integrase of the Tn916-Tn1545 family of conjugative transposons was detected in three $L$. saliavrius isolates (22a, 28a, 30a). Its presence was in coexistence with tet $M$ and tet $L$, and the two isolates also contained the ermB gene.

\section{Nitrocefin test}

The results of the nitrocefin test for the rapid chromogenic detection of beta-lactamase activity [24] was negative for all Lactobacillus isolates phenotypically resistant to ampicillin.

\section{Discussion}

In this paper we have presented the first report on the identification and antibiotic susceptibility of lactobacilli from farm turkeys.

Bacteria were identified to the species level using MALDI-TOF MS and, if uncertain results were obtained, identification was further based on $16 \mathrm{~S}$ rDNA analysis. The reliability and effectiveness of MALDI-TOF MS in typing lactobacilli has been confirmed by several authors and high agreement has been observed between results obtained in mass spectrometry and in various genetic methods, even if the $\log$ (score) values were lower than $2.00[13,25,26]$. However, in this work we found that MALDI-TOF MS had insufficient discriminatory power to differentiate closely related species such as L. johnsonii and L. gasseri, L. crispatus and L. ultunensis, and $L$. oris and $L$. antri. Homology between $L$. 
johnsonii and L. gasseri at the sequence level of $16 \mathrm{~S}$ rDNA and other genes is known to be very high [27], and the similarity of the $16 \mathrm{~S}$ rDNA sequence between L. crispatus and L. ultunensis and between L. oris and L. antri has been estimated at $98.2 \%$ and $99.8 \%$, respectively [28]. The results of our work showed that the genetic similarity between these species translates into similarity in cellular protein profiles. However, as shown by restriction analysis of $16 \mathrm{~S}$ rDNA, despite high homology between mass spectra of closely related species, the first best match $(\log ($ score $) \geq 1.70)$ was correct for all questionable samples. The issue of ambiguous differentiation of closely related Lactobacillus species in MALDI-TOF MS, including L. johnsonii and L. gasseri, has been addressed also in our earlier paper [13].

The Lactobacillus species identified in this study in isolates from turkeys are similar to those found in poultry worldwide. Several reports have pointed out the predominance of Lactobacillus crispatus, $L$. salivarius, $L$. reuteri and $L$. johnsonii among intestinal autochthonic chicken lactobacilli $[29,30]$. In Poland, the dominant Lactobacillus species in geese and chickens are L. salivarius and $L$. johnsonii, and the remaining species which have been identified in turkeys, i.e. L. crispatus, L. ingluviei, $L$. reuteri, $L$. oris, $L$. agilis and $L$. saerimneri, were isolated with a lower frequency $[25,31]$.

Among the lactobacilli tested we found high prevalence of resistance to tetracycline (68\% resistant isolates), lincomycin (64.5\%), enrofloxacin (60\%) and ampicillin (50\%). The frequency of resistance to other amicrobial agents, i.e. erythromycin, aminoglycosides and chloramphenicol, ranged from $10 \%$ to $45 \%$. The high level of antibiotic resistance observed in this study is probably due to the widespread use of antimicrobial drugs on turkey farms. The history of the use of antibiotics in the flocks from which Lactobacillus isolates were derived was not made available. However, according to the inspection carried out in Poland in 2015-2016 by the Supreme Audit Office, antibiotics were detected in $88 \%$ of turkey farms (in water or feed). The standards for doxycycline and enrofloxacin were exceeded most often, and antibiotics most commonly used in Poland in animal husbandry include tetracyclines and penicillins [32]. These facts may justify the high prevalence of resistance to ampicillin, tetracycline and enrofloxacin in the tested lactobacilli.

High prevalence of tetracycline resistance (68\% of isolates) in turkey lactobacilli is in line with our earlier research demonstrating that $75 \%$ of Lactobacillus isolates from chickens in Poland are resistant to this antibiotic [16]. Similar results obtained also Cauwerts et al. [33], who recorded nearly $80 \%$ resistance to tetracycline among lactobacilli from Belgian broiler farms. The observed tetracycline resistance was due to the presence of tet genes, which code for energy-dependent efflux proteins $($ tet $L)$ or for a protein that protects bacterial ribosomes from the action of tetracyclines (tet $M$, tet $W$ ) [34]. The incidence of tet $L$, tet $M$ and tet $W$ genes in turkey lactobacilli is similar to that occurring in Lactobacillus isolates from chicken farms in Poland and Belgium [16, 33]. The tet $W$ and tet $M$ genes are also widespread in Lactobacillus bacteria isolated from humans and food products [35]. Our finding that the tetW gene is characteristic for the isolates belonging to the phylogenetic group $L$. delbrueckii and $L$. reuteri, and that its occurrence among isolates of the $L$. salivarius group is sporadic, is consistent with previous research on chicken lactobacilli [16].

The high rates of resistance (45-63\%) to MLS antibiotics (macrolides, lincosamides and streptogramins) observed in turkey lactobacilli are in line with our recent study showing that $70 \%$ of lactobacilli derived from chickens in Poland were resistant to lincomycin and $42 \%$ were resistant to macrolides [16]. Similar findings were reported by Cauwerts et al. [19] for Lactobacillus bacteria isolated from broiler chicken in Belgium. The bimodal distribution of MIC values for erythromycin, which suggests acquired resistance, has been also recorded earlier for lactobacilli of various origins $[19,36]$.

Phenotypic resistance to MLS antibiotics in the turkey lactobacilli was associated with the presence of erm genes, which encode rRNA methylases, and the $\ln u A$ gene, which encodes lincosamide $O$-nucleotidyltransferase. The high incidence of the ermB gene (in $45 \%$ of isolates) and the lower incidence of erm C (6\%) is consistent with previous studies on the antibiotic susceptibility of chicken Lactobacillus strains [16, 19]. In contrast, the frequency of the $\ln u A$ gene in turkey lactobacilli (18\%) was about half of that noted in chicken isolates (39\%) in Poland, although phenotypic resistance to lincomycin was very similar in both species [16]. The presence of the erm $C$ gene not only in resistant but also MLS-suseptible Lactobacillus isolates has also previously been reported by other authors [16, 25].

The incidence of ampicillin resistance (47\% resistant isolates) recorded in this study is much higher than that observed by other researchers working on poultry LAB $[37,38]$. The ampicillin resistance rate in chicken lactobacilli (26\%) from Polish farms is almost half that of turkey Lactobacillus isolates [16]. High MIC values for ampicillin $(\geq 64 \mu \mathrm{g} / \mathrm{ml})$ recorded for $24 \%$ isolates were usually accompanied by elevated MICs for first, second and thirs generation cephalosporins $(\geq 16 \mu \mathrm{g} / \mathrm{ml})$ indicating cross-resistance. The mechanism of resistance of the lactobacilli to ampicillin remained unexplained, but the results of the tests carried out excluded the involvement of $\beta$-lactamases. This is line with studies by other authors [23, 39], who have demonstrated the absence of 
the blaZ gene encoding $\beta$-lactamase in lactobacilli phenotypically resistant to penicillins. The third generation cephalosporins are usually highly resistant to Blactamases.

Among turkey lactobacilli, 30\% of isolates showed resistance to chloramphenicol, and for most of them (12 of 18 phenotypically resistant) the MIC was $8 \mu \mathrm{g} / \mathrm{ml}$, while the EFSA threshold is $4 \mu \mathrm{g} / \mathrm{ml}$. Higher MIC values, i.e. $16-128 \mu \mathrm{g} / \mathrm{ml}$, and the presence of the chloramphenicol acetyltransferase cat gene were characteristic only for L. ingluviei isolates, although two cat-positive strains were considered phenotypically susceptible. A similar range of MIC values for chloramphenicol, i.e. 1-8 $\mu \mathrm{g} / \mathrm{ml}$ for most lactobacilli tested, has been observed by other authors $[16,39,40]$, while high MIC values $\geq 32 \mu \mathrm{g} / \mathrm{ml}$ have been noted only occasionally $[14,16,40]$. The presence of the cat gene among chloramphenicol-susceptible Lactobacillus isolates has also been observed in our previous work, and more precise studies by Hummel et al. [23] showed that the cat gene was not expressed (RNA level) in some cat-positive but phenotypically susceptible LAB strains.

In this work, we observed a fairly high frequency of resistance to streptomycin (31\%), while gentamicin resistance was much less prevalent (10\%). A similar percentage (12.5-31\%) of aminoglycoside-resistant strains was recorded for chicken lactobacilli in Poland [16]. More frequent occurrence of resistance to streptomycin than to gentamicin among lactobacilli from various sources was also demonstrated by Danielsen and Wind [40]. Of the genes that determine resistance to aminoglycosides, only two are found in, ie. aadE and ant(6)-Ia, in 3 isolates of $L$. salivarius showing phenotypic resistance to streptomycin. According to Ramires and Tolmasky [41], aadE and ant(6)-Ia encode O-adenyltransferases that confer resistance to streptomycin and belong to the ANT(6) group of modifying enzymes but the results of sequence analysis of PCR products indicated that $a a d E$ and ant(6)-Ia are the same gene detected by different primers. The aadE or ant(6)-Ia gene has been previously detected in L. salivarius strains from chicken [16] and in L. casei and L. plantarum isolates from food sources or human biopsy samples [42].

The present study provides the second report on the sensitivity of lactobacilli to tiamulin. In our previous work on chicken lactobacilli, we proposed a concentration of $8 \mu \mathrm{g} / \mathrm{ml}$ as a breakpoint for distinguishing sensitive and resistant strains. In the present study we have not adopted this cut-off point, nor have we proposed other breakpoint values, due to the MIC distribution and insufficient number of isolates of most Lactobacillus species. However, the high MIC values of tiamulin, i.e. $\geq 32 \mu \mathrm{g} / \mathrm{ml}$, noted in the majority $(61 \%)$ of turkey lactobacilli suggest the prevalence of resistance to this antibiotic. As in the earlier studies on chicken lactobacilli [16] only $10 \%$ isolates were tiamulin MIC values as low as $\leq 0.5 \mu \mathrm{g} / \mathrm{ml}$. The genetic resistance of most Lactobacillus strains with high MIC values for tiamulin has not been determined. The $l s a E$ gene that codes for ATP-dependent drug efflux pump was detected only in 3 L. salivarius isolates with high MIC values (128-256 $\mu \mathrm{g} / \mathrm{ml}$ ) of tiamulin. Therefore, it is likely that the low sensitivity of the lactobacilli to this pleuromutulin is the modification of the target, i.e. 23S rRNA at the peptidyl transferase center of the 50S subunit [43]. All lasE-positive isolates simultaneously contained the $a a d E /$ ant(6)-Ia gene conferring resistance to streptomycin. This observation is in line with our recent findings on chicken lactobacilli [16] and previous reports describing the occurrence of $l s a E$ within plasmid or chromosomal clusters comprising several resistance genes, including $\operatorname{aadE}[44]$.

The percentage of enrofloxacin-resistant Lactobacillus strains $(\mathrm{MIC} \geq 64 \mu \mathrm{g} / \mathrm{ml})$ in the turkeys $(60 \%)$ was higher than in chickens (48\%) and in geese (23\%) in Poland $[16,45]$. Lactobacilli from other sources, such as dairy products or cattle intestine, are usually sensitive to enrofloxacin $[46,47]$.

The $\operatorname{Tn} 916 / \operatorname{Tn} 1545$-like coniugative transposon that was identified in three strains of $L$. salivarius, is commonly found in various bacteria, including entrococci and streptococci, but not in lactobacilli $[48,49]$. The coexistence of integrase gene int-tn and tet $M$, tet $L$ and ermB genes observed in these studies is consistent with the literature data, according to which members of the Tn916-Tn1545 family carry the tetracycline-resistance determinant tet $M$, as well as additional resistance genes [49].

\section{Conclusions}

Our work is the first report on the identification and antibiotic susceptibility of Lactobacillus bacteria from turkeys. We have shown the predominance of $L$. salivarius (35\%) and L. crispatus (21\%) among turkey lactobacilli and a high frequency of resistance $(\geq 45 \%$ resistant isolates) to tetracycline, lincomycin, ampicillin and erythromycin. These data indicate that antibiotic resistance has reached a dangerous level in the commensal microflora, and the high rate of ampicillin resistance thus far observed in lactobacilli is particularly alarming. There is need to promote the rational use of antibiotics in poultry farming to limit the development of resistance in bacteria. More emphasis should be placed on alternative therapies and the implementation of biosecurity practices, which are the most effective, cheapest and safest way to prevent the spread of disease on farms. Consideration should also be given to amending legislation 
governing the use of antibiotics in livestock. The level of antibiotic resistance may be reduced by introducing an obligation to report to the regulatory authorities the use of antibiotics on farm and by requiring antibiotic resistance tests before antibiotic use.

Our studies have shown that the natural intestinal microflora of turkeys is a reservoir of resistance genes. Many of them were previously found in LAB on the mobile elements, which can be readily transferred to other bacteria inhabiting the intestine of the host and spread in the environment $[9,48]$. Further research is needed to clarify the mechanism of low sensitivity of lactobacilli to beta-lactam antibiotics and pleuromutilins.

\section{Additional files}

Additional file 1: Table S1. Containing the results of sequencing PCR products (for representative wild-type isolates) that are counterparts of resistance genes and results of comparative analysis of the obtained sequences with the reference sequences deposited at GenBank. (DOC $155 \mathrm{~kb}$ )

Additional file 2: Table S2. Containing original data on the identification of bacteria by MALDI-TOF MS, MIC values and the occurrence of resistance genes. (XLS $75 \mathrm{~kb}$ )

Additional file 3: Table S3. Containing sizes (bp) of restriction fragments obtained by cleavage of $16 \mathrm{~S}$ rDNA amplicons of reference and wild-type isolates of Lactobacillus. (DOC $31 \mathrm{~kb}$ )

\section{Abbreviations}

16S-ARDRA: Amplified Ribosomal DNA Restriction Analysis of $165 \mathrm{rDNA}$; dNTPs: Deoxynucleoside triphosphates; EFSA's FEEDAP Panel: European Food Safety Authority Panel on Additives and Products or Substances used in Animal Feed; G+C: Guanine + cytosine; GIT: Gastrointestinal tract; LAB: Lactic acid bacteria; LSM: LAB susceptibility test medium; MALDI-TOF MS: Matrix assisted laser desorption ionization-time of flight mass spectrometry; MIC: Minimal inhibitory concentration; MLS: Macrolides, lincosamides and streptogramins; MRS: Man, Rogosa and Sharp; PCR: Polymerase chain reaction; rDNA: Ribosomal deoxyribonucleic acid; rRNA: Ribosomal ribonucleic acid

\section{Acknowledgements}

The authors thank Prof. Stanisław Winiarczyk for shering mass spectrometer during identification of lactobacilli using MALDI-TOF MS and Krzysztof Bourdo, DVM, for his assistance in collecting the samples from turkeys.

\section{Funding}

The research was financed by the Polish National Science Centre (NCN), project no. 2017/01/X/NZ8/00478. The funds received were used to purchase the materials necessary to perform the tests. The financing body did not participate in research design, analysis of results or writing of the manuscript.

\section{Availability of data and materials}

All data generated or analysed during this study are included in this published article and its supplementary information files.

\section{Authors' contributions}

MD designed the study, performed laboratory tests regarding genetic differentiation of lactobacilli, determination of MICs and detection of resistance genes, interpreted the data, supervised all experiments and drafted the manuscript. AN and DS-P were responsible for collecting the test material, isolating lactobacilli and performing DNA electroporesis. JW identified bacteria by MALDI-TOF MS. RU-C isolated DNA from bacteria. All authors read and approved the final manuscript.

\section{Ethics approval and consent to participate}

The faecal samples and cloacal from the birds were collected by a veterinarian as part of his work. According to Polish law (the act on experiments on animals of 21 January 2005), permission from the ethics commission is not required for this type of sample collection. All animal owners agreed to collect material for testing.

Consent for publication

Not applicable.

\section{Competing interests}

The authors declare that they have no competing interests.

\section{Publisher's Note}

Springer Nature remains neutral with regard to jurisdictional claims in published maps and institutional affiliations.

\section{Author details}

'Department of Veterinary Prevention and Avian Diseases, Institute of Biological Bases of Animal Diseases, Faculty of Veterinary Medicine, University of Life Sciences in Lublin, Akademicka 12, 20-033 Lublin, Poland.

${ }^{2}$ Department of Biochemistry, Faculty of Veterinary Medicine, University of Life Sciences in Lublin, Akademicka 12, 20-033 Lublin, Poland.

Received: 19 October 2017 Accepted: 27 September 2018

Published online: 29 October 2018

\section{References}

1. Felis GE, Dellaglio F. Taxonomy of lactobacilli and bifidobacteria. Curr Issues Intest Microbiol. 2007:8:44-61.

2. NCBI database, http://www.ncbi.nlm.nih.gov/taxonomy

3. Sun Z, Yu J, Dan T, Zhang W, Zhang H. Phylogenesis and Evolution of Lactic Acid Bacteria. In: Zhang H, Cai Y, editors. Lactic Acid Bacteria: Fundamentals and Practice. Dordrecht: Springer; 2014. p. 1-101.

4. Lebeer S, Vanderleyden J, De Keersmaecker SC. Genes and molecules of lactobacilli supporting probiotic action. Microbiol Mol Biol Rev. 2008;72:728-64.

5. Biegański M. Produkcja indyków w Polsce w 2016 r. Indyk Polski. 2017;58: 34-9.

6. Gehring AR. The Homesteading Handbook: A Back to Basics Guide to Growing Your Own Food, Canning, Keeping Chickens, Generating Your Own Energy, Crafting, Herbal Medicine, and More (The Handbook Series). New York: Skyhorse Publishing; 2011. p. 147-8.

7. Agunos A, Carson C, Léger D. Antimicrobial therapy of selected diseases in turkeys, laying hens, and minor poultry species in Canada. Can Vet J. 2013; 54:1041-52

8. Schiøring S, Krogfelt KA. Assessment of bacterial antibiotic resistance transfer in the gut. Int J Microbiol. 2011;2011:1-10.

9. Devirgiliis C, Zinno P. Perozzi G. Update on antibiotic resistance in foodborne Lactobacillus and Lactococcus species. Front Microbiol. 2013;4:301.

10. Gueimonde M, Sánchez B, de Los Reyes-Gavilán CG, Margolles A. Antibiotic resistance in probiotic bacteria. Front Microbiol. 2013;4:202.

11. Friedman ND, Temkin E, Carmeli Y. The negative impact of antibiotic resistance. Clin Microbiol Infect. 2016:22:416-22.

12. Guidance on the assessment of bacterial susceptibility to antimicrobials of human and veterinary importance. EFSA Journal 2012;10:2740.

13. Dec M, Puchalski A, Urban-Chmiel R, Wernicki A. 16S-ARDRA and MALDITOF mass spectrometry as tools for identification of Lactobacillus bacteria isolated from poultry. BMC Microbiol. 2016;16:105.

14. Mayrhofer S, Van Hoek AH, Mair C, Huys G, Aarts HJ, Kneifel W, Domig KJ. Antibiotic susceptibility of members of the Lactobacillus acidophilus group using broth microdilution and molecular identification of their resistance determinants. Int. J. Food Microbiol. 2010;144:81-7.

15. Dec M, Urban-Chmiel R, Stepień-Pyśniak D, Wernicki A. Assessment of antibiotic susceptibility in Lactobacillus isolates from chickens. Gut Pathog. 2017;9:54

16. Klare I, Konstabel C, Müller-Bertling S, Reissbrodt R, Huys G, Vancanneyt M, Swings J, Goossens H, Witte W. Evaluation of new broth media for microdilution antibiotic susceptibility testing of Lactobacilli, Pediococci, Lactococci, and Bifidobacteria. Appl Environ Microbiol. 2005;71:8982-6.

17. CLSI document M100-S25. Performance Standards for Antimicrobial Susceptibility Testing; Twenty-Fifth Informational Supplement. 2015 
18. CLSI document Vet01S. Performance Standards for Antimicrobial Disk and Dilution Susceptibility Tests for Bacteria Isolated From Animals. 3rd ed; 2015.

19. Cauwerts K, Pasmans F, Devriese LA, Martel A, Haesebrouck F, Decostere A. Cloacal Lactobacillus isolates from broilers show high prevalence of resistance towards macrolide and lincosamide antibiotics. Avian Pathol. 2006:35:160-4.

20. Malhotra-Kumar S, Lammens C, Piessens J, Goossens H. Multiplex PCR for simultaneous detection of macrolide and tetracycline resistance derminants in streptococci. Antimicrob Agents Chemother. 2005;49:4798-800.

21. Vakulenko SB, Donabedian SM, Voskresenskiy AM, Zervos MJ, Lerner SA, Chow JW. Multiplex PCR for detection of aminoglycoside resistance genes in enterococci. Antimicrob Agents Chemother. 2003;47:1423-6.

22. Van $\Pi$ T, Chin J, Chapman T, Tran LT, Coloe PJ. Safety of raw meat and shellfish in Vietnam: an analysis of Escherichia coli isolations for antibiotic resistance and virulence genes. Int J Food Microbiol. 2008;124:217-23.

23. Hummel AS, Hertel C, Holzapfel WH, Franz CM. Antibiotic resistances of starter and probiotic strains of lactic acid bacteria. Appl Environ Microbiol. 2007;73:730-9.

24. Bidya S, Suman RS. Comparative Study of Three $\beta$ Lactamase Test Methods in Staphylococcus aureus Isolated from Two Nepalese Hospitals. OJCD. 2014:4:47-52.

25. Dec M, Urban-Chmiel R, Gnat S, Puchalski A, Wernicki A. Identification of Lactobacillus strains of goose origin using MALDI-TOF mass spectrometry and 16S-23S rDNA intergenic spacer PCR analysis. Res Microbiol. 2014;165: 190-201.

26. Anderson AC, Sanunu M, Schneider C, Clad A, Karygianni L, Hellwig E, et al. Rapid species-level identification of vaginal and oral lactobacilli using MALDI-TOF MS analysis and 165 rDNA sequencing. BMC Microbiol. 2014;14:312

27. Azcarate-Peril MA, Altermann E, Goh YJ, Tallon R, Sanozky-Dawes RB, Pfeile EA, O'Flaherty S, Buck BL, Dobson A, Duong T, Miller MJ, Barrangou R, Klaenhammer TR. Analysis of the genome sequence of Lactobacillus gasseri ATCC 33323 reveals the molecular basis of an autochthonous intestinal organism. Appl Environ Microbiol. 2008;74:4610-25.

28. Roos S, Engstrand L, Jonsson H. Lactobacillus gastricus sp. nov., Lactobacillus antri sp. nov., Lactobacillus kalixensis sp. nov. and Lactobacillus ultunensis sp. nov., isolated from human stomach mucosa. Int J Syst Evol Microbiol. 2005; $55: 77-82$.

29. Abbas Hilmi HT, Surakka A, Apajalahti J, Saris PE. Identification of the most abundant Lactobacillus species in the crop of 1- and 5-week-old broiler chickens. Appl Environ Microbiol. 2007;73:7867-73.

30. Vidanarachchi JK, Mikkelsen LL, lji PA, Choct M. Molecular characterisation of lactobacilli isolated from ileal and caecal digesta of broilers fed with prebiotic plant extracts. Tropical Agricultural Research. 2007;19:46-51.

31. Dec M, Puchalski A, Nowaczek A, Wernicki A. Antimicrobial activity of Lactobacillus strains of chicken origin against bacterial pathogenss. Int Microbiol. 2016:19:57-67.

32. Report of Supreme Audit Office. Wykorzystywanie antybiotyków w produkcj zwierzęcej w województwie lubuskim; 2017. p. 1-75. http://www.nik.gov.pl.

33. Cauwerts K, Pasmans F, Devriese LA, Haesebrouck F, Decostere A. Cloacal Lactobacillus isolates from broilers often display resistance toward tetracycline antibiotics. Microb Drug Resist. 2006;12:284-8.

34. Chopra I, Roberts M. Tetracycline antibiotics: mode of action, applications, molecular biology, and epidemiology of bacterial resistance. Microbiol Mol Biol Rev. 2001;65:232-60.

35. Klare I, Konstabel C, Werner G, Huys G, Vankerckhoven V, Kahlmeter G, Hildebrandt B, Müller-Bertling S, Witte W, Goossens H. Antimicrobial susceptibilities of Lactobacillus, Pediococcus and Lactococcus human isolates and cultures intended for probiotic or nutritional use. J Antimicrob Chemother. 2007:59:900-12.

36. Delgado S, Flórez AB, Mayo B. Antibiotic susceptibility of Lactobacillus and Bifidobacterium species from the human gastrointestinal tract. Curr Microbiol. 2005;50:202-7

37. Kmet $\mathrm{V}$, Piatnicová E. Antibiotic resistance in commensal intestinal microflora. Folia Microbiol (Praha). 2010;55:332-5

38. Lonkar P, Harne SD, Kalorey DR, Kurkure NV. Isolation, in vitro antibacterial activity, bacterial sensitivity and plasmid profile of lactobacilli. Asian-Aust $J$ Anim Sci. 2005:18:1336-42

39. Mayrhofer S, Zitz U, Birru FH, Gollan D, Gołoś AK, Kneifel W, Domig KJ. Comparison of the CLSI quideline and ISO/IDF standard for antimicrobial susceptibility testing of lactobacilli. Microb Drug Resist. 2014;20:591-603.
40. Danielsen M, Wind A. Susceptibility of Lactobacillus spp. to antimicrobial agents. Int J Food Microbiol. 2003:26:1-11.

41. Ramirez MS, Tolmasky ME. Aminoglycoside modifying enzymes. Drug Resist Updat. 2010;13:151-71.

42. Ouoba LI, Lei V, Jensen LB. Resistance of potential probiotic lactic acid bacteria and bifidobacteria of African and European origin to antimicrobials: determination and transferability of the resistance genes to other bacteria. Int J Food Microbiol. 2008;121:217-24.

43. van Duijkeren E, Greko C, Pringle M, Baptiste KE, Catry B, Jukes H, Moreno MA, Pomba MC, Pyörälä S, Rantala M, Ružauskas M, Sanders P, Teale C, Threlfall EJ, Torren-Edo J, Törneke K. Pleuromutilins: use in food-producing animals in the European Union, development of resistance and impact on human and animal health. J Antimicrob Chemother. 2014;69:2022-31.

44. Si H, Zhang WJ, Chu S, Wang XM, Dai L, Hua X, Dong Z, Schwarz S, Liu S. Novel plasmid-borne multidrug resistance gene cluster including $I s a(E)$ from a linezolid-resistant Enterococcus faecium isolate of swine origin. Antimicrob Agents Chemother. 2015;59:7113-6.

45. Dec M, Wernicki A, Puchalski A, Urban-Chmiel R. Antibiotic susceptibility of Lactobacillus strains isolated from domestic geese. Br Poult Sci. 2015; 56:416-24.

46. Ishihara K, Nakajima K, Kishimoto S, Atarashi F, Muramatsu Y, Hotta A, Ishii S, Takeda Y, Kikuchi M, Tamura Y. Distribution of antimicrobialresistant lactic acid bacteria in natural cheese in Japan. Microbiol Immunol. 2013:57:684-91.

47. Korhonen J. Antibiotic Resistance of Lactic Acid Bacteria Dissertations in Forestry and Natural Sciences. Kuopio: Publications of the University of Eastern Finland Dissertations in Forestry and Natural Sciences; 2010.

48. Gevers D, Danielsen M, Huys G, Swings J. Molecular characterization of tet(M) genes in Lactobacillus isolates from different types of fermented dry sausage. Appl Environ Microbiol. 2003;69:1270-5.

49. Clewell DB, Flannagan SE, Jaworski DD. Unconstrained bacterial promiscuity: the Tn916-Tn1545 family of conjugative transposons. Trends Microbiol. 1995:3:229-36.

50. Masco L, Van Hoorde K, De Brandt E, Swings J, Huys G. Antimicrobial susceptibility of Bifidobacterium strains from humans, animals and probiotic products. J Antimicrob Chemother. 2006;58:85-94.

51. Kastner S, Perreten V, Bleuler H, Hugenschmidt G, Lacroix C, Meile L. Antibiotic susceptibility patterns and resistance genes of starter cultures and probiotic bacteria used in food. Sys Appl Microbiol. 2006;29:145-55.

52. Kobayashi N, Alam M, Nishimoto Y, Urasawa S, Uehara N, Watanabe N. Distribution of aminoglycoside resistance genes in recent clinical isolates of Enterococcus faecalis, Enterococcus faecium and Enterococcus avium. Epidemiol Infect. 2001;126:197-204

53. Li XS, Dong WC, Wang XM, Hu GZ, Wang YB, Cai BY, Wu CM, Wang Y, Du $X D$. Presence and genetic environment of pleuromutilin-lincosamidestreptogramin A resistance gene $1 \mathrm{sa}(\mathrm{E})$ in enterococci of human and swine origin. J Antimicrob Chemother. 2014;69:1424-6.

54. Garofalo C, Vignaroli C, Zandri G, Aquilanti L, Bordoni D, Osimani A Clementi F, Biavasco F. Direct detection of antibiotic resistance genes in specimens of chicken and pork meat. Int J Food Microbiol. 2007;113:75-83.

55. Lee JH. Methicillin (Oxacillin)-resistant Staphylococcus aureus strains isolated from major food animals and their potential transmission to humans. Appl Environ Microbiol. 2003:69:6489-94.

Ready to submit your research? Choose BMC and benefit from:

- fast, convenient online submission

- thorough peer review by experienced researchers in your field

- rapid publication on acceptance

- support for research data, including large and complex data types

- gold Open Access which fosters wider collaboration and increased citations

- maximum visibility for your research: over $100 \mathrm{M}$ website views per year

At BMC, research is always in progress.

Learn more biomedcentral.com/submission 